\title{
The Banking and Cryopreservation of Human Embryonic Stem Cells
}

\author{
Charles J. Hunt \\ UK Stem Cell Bank, National Institute for Biological Standards and Control, South Mimms, Potters Bar, UK
}

\section{Key Words}

Embryonic stem cells · Human · Cell line ·

Cryopreservation - Vitrification

\section{Summary}

Human embryonic stem cells are pluripotent cells derived from the inner cell mass of the blastocyst. Once isolated in culture, they can produce stable cell lines with the capacity to provide differentiated cells from all three germ layers. This ability is the centre of an emerging field of research into applications ranging from tissue engineering and drug discovery to developmental biology and treatments for serious conditions such as Parkinson's, diabetes and heart disease. An essential prerequisite for these developments is the production of banks of well-characterised and safety-tested cells for research and as seed stocks for therapeutic applications. This requires the cryopreservation of stem cells for long-term storage. Currently, conventional freezing and vitrification when applied to these cells has met with varying degrees of success. This has led to an emerging debate on the suitability of either method for cryopreservation of these cells. Such studies as have been undertaken have been empirical in nature, and to date, no methodological studies, such as those carried out on haematopoietic stem cells, have been published. This paper reviews the current debate on cryopreservation and places it in the context of stem cell banking for both research and therapy.

\author{
Schlüsselwörter \\ Embryonale Stammzellen · Human - Zelllinie · \\ Kryokonservierung · Vitrifizierung
}

\section{Zusammenfassung}

Humane embryonale Stammzellen sind pluripotente Zellen, die aus der inneren Zellmasse der Blastozysten stammen. Einmal in Kultur gebracht können sie stabile Zelllinien initiieren, welche die Fähigkeiten differenzierter Zellen aus allen drei Keimblättern haben. Diese Fähigkeit ist der Dreh- und Angelpunkt von Forschungsaktivitäten, die von "tissue engineering" und "drug discovery" über Entwicklungsbiologie bis zur Behandlung ernsthafter Erkrankungen wie Parkinson, Diabetes und Herzerkrankungen reichen. Eine essentielle Voraussetzung für diese Entwicklungen ist die Schaffung von Zellbanken mit gut charakterisiertem und hinsichtlich der Sicherheit ausgetestetem Ausgangsmaterial für therapeutische Anwendungen. Dies erfordert wegen der Langzeit-Haltbarmachung die Anwendung von Kryokonservierungsverfahren. Derzeit sind die beiden dafür angewandten Verfahren - nämlich konventionelles Einfrieren und Vitrifizierung - von wechselnden Erfolgen gekrönt. Die bislang durchgeführten Untersuchungen waren naturgemäß empirisch, und bis heute wurden noch keine methodologischen Untersuchungen, wie sie z.B. mit hämatopoetischen Stammzellen durchgeführt worden sind, publiziert. Diese Übersichtsarbeit fasst die derzeitige Debatte über die verschiedenen Kryokonservierungsverfahren für Stammzellen zusammen, und zwar sowohl die Forschung als auch die Anwendung betreffend.

\begin{tabular}{ll}
\hline KARGER & @ 2007 S. Karger GmbH, Freiburg \\
$\begin{array}{l}\text { Fax +49 76145207 14 } \\
\begin{array}{l}\text { E-mail Information@Karger.de } \\
\text { www.karger.com }\end{array}\end{array}$ & $\begin{array}{l}\text { Accessible online at: } \\
\text { www.karger.com/tmh }\end{array}$
\end{tabular}




\section{Background}

Although mouse embryonic stem cells (mESC) were first isolated as far back as 1981 [1], it was not until 1994 that human embryonic stem cells (hESC) were derived from surplus in vitro fertilised blastocysts [2]. However, these cells spontaneously differentiated after only minimal time in culture. Thomson et al. [3] established the first hESC line capable of long-term culture in 1998. Two years latter, Reubinoff et al. [4] confirmed that embryonic stem cell (ESC) lines could be derived efficiently from surplus embryos and demonstrated the ability of these cells to differentiate in vitro into cells from all three germ layers.

This ability to produce a theoretically unlimited supply of normal, differentiated cells has drawn wide attention to the potential importance of hESC in areas as diverse as developmental biology, toxicology [5], cell therapy [6], tissue engineering [7] and gene therapy [8].

It is in the area of cellular therapy, for such diverse diseases as Parkinson's, diabetes, Alzheimer's, heart disease, stroke and spinal cord injury, where initial activity has been concentrated. This has been sparked by two decades of research leading to controlled differentiation of mESC to insulin-producing cells, dopaminergic neurons, cardiomyocytes and haematopoietic progenitors, and which has pointed the way for studies on the differentiation of human stem cells toward these cell types. Though there is still only a rudimentary understanding of the signalling pathways required to control the differentiation of hESC, there has been some success in enriching the differentiated stem cell populations for a number of these lineages [9-13].

In addition to controlling differentiation, commercial application of hESC to areas such as drug discovery will also require scale-up of current methods of processing: an area which provides substantial challenges not only in bioprocessing but also in the production of cells in formats suitable for commercial use [5]. Moreover, in addition to the application-specific problems, effective methods for cryopreservation, storage and delivery of hESC will be required both for research and patient therapy.

\section{The Embryonic Stem Cell and the Derivation of Stem Cell Lines}

\section{The Embryonic Stem Cell}

hESC are pluripotent cells derived from the inner cell mass (ICM) of the pre-implantation embryo [14]. They are characterised functionally by two features: their ability for continuous self-renewal during extended periods in culture, and their continued capacity during culture for asymmetric division: generating daughter cells which may then give rise to multiple types of differentiated cells from all three embryonic germ layers.

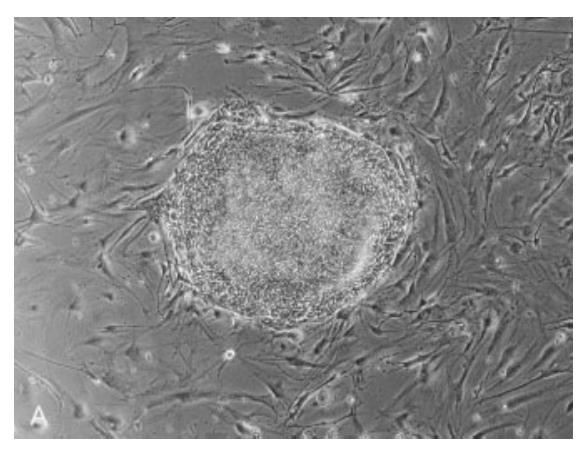

Fig. 1. Typical morphology of hESC colonies. A Undifferentiated hESC colony. B hESC colony showing 'fried-egg' appearance with a central area of undifferentiated cells surrounded by differentiated cells. The fibroblastlike cells surrounding the colony are the inactivated mouse feeder cells. (Photographs courtesy of L Young and L Healy, copyright NIBSC)

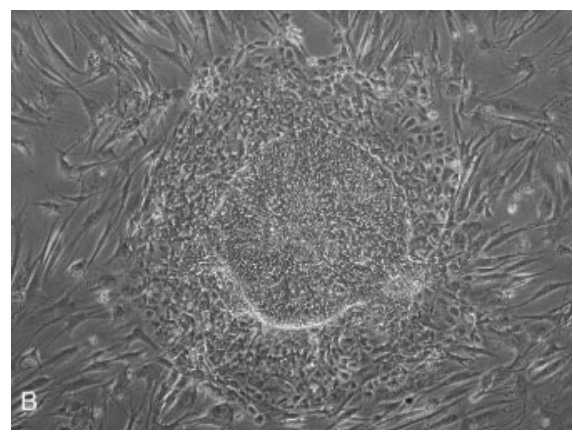

Morphologically, the cells have a high nuclear to cytoplasm ratio, generally forming flat colonies in vitro (fig. 1). Phenotypically, and in contrast to mESC, they do not express the stage-specific embryonic antigen SSEA-1 but, like ICM cells, they express SSEA-3 and SSEA-4. They are also recognised by a set of antibodies to human embryonal carcinoma (EC) cells that includes TRA-1-60 and TRA-1-81. hESC also express CD9, CD133 (both expressed by other stem cell populations), Thy 1 and major histocompatibility complex class 1 [15], as well as the intracellular transcription factor Oct3/4. Expression of these markers is maintained following prolonged periods in culture, though quantitatively, expression levels vary.

Undifferentiated hESC show high levels of alkaline phosphatase and telomerase activity and also maintain a normal karyotype over extended periods in culture. There have been occasional reports of abnormal karyotypes, notably trisomy 13 and 17; similar to those abnormalities observed in human EC cells [16]. Abnormalities to chromosomes 2 and 12 after prolonged serial culture have also been described [17].

\section{Derivation of Embryonic Stem Cell Lines}

Policies on stem cell research and the derivation of hESC lines vary widely throughout the world and within the member states of the European Union. These policies are often complex and change frequently. At the present time in Germany for instance, derivation of hESC lines is prohibited under its 1991 Embryo Protection Act. Recently, the Stem Cell Act (2002) prohibited the import and use of hESC unless the stem cell lines conformed to certain criteria including their derivation before January 2002. Austria currently prohibits research on, and derivation of, hESC though there are moves to modify 
this position. On the other hand Switzerland, with its enactment of the Stem Cell Research Act (2005) has recently moved to permit hESC research along similar lines to those of the UK. An overview of current policies toward stem cell research can be found on the International Society for Stem Cell Research (ISSCR) website (www.isscr.org/public/regions/ index.cfm).

In the UK, hESC lines are derived from ethically sourced embryos donated for research after informed consent has been obtained from the donor. These are embryos that are unsuitable for, or surplus to, the clinical requirements of in vitro fertilization (IVF) or pre-implantation genetic diagnosis (PGD) [18]. All such activity is licensed by the Human Fertilisation and Embryology Authority (HFEA) who ensure, through their inspection and licensing regime, high levels of ethical review (www.hfea.gov.uk).

Though first derived from the ICM of the blastocyst stage (days 5-8), methods have since been developed to derive hESC from the late morula stage [19], from arrested embryos [20] and from single blastomeres [21]. Many of the early stem cell lines were derived by immunosurgery using animal antibodies (e.g. guinea pig complement) followed by plating of the ICM onto irradiated or mitomycin-C-inactivated mouse embryonic fibroblasts in tissue culture medium containing animal serum. These cells appear to be required for growth of human (and animal) ESC and are termed feeder cells or feeders. The ICM-hESC colonies thus generated are mechanically dissected and transferred to fresh, inactivated feeders. A cell line can, in some circumstances, be established from these colonies by subsequent mechanical dissection and serial passaging at intervals onto fresh feeders.

The use of animal material in the generation of these lines has had implications in the use of stem cells for clinical therapy. More recently, with a view to providing stem cells that are suitable for clinical application, cell lines have been generated using a 'whole embryo culture' method with plating onto human feeders in serum-free medium [22]. Once a cell line has been established, seed stocks of cryopreserved material are required to ensure the availability of the cell line for future research and clinical application. This is one of the many activities undertaken by the UK Stem Cell Bank [23].

\section{The UK Stem Cell Bank}

Following a report from the UK Chief Medical Officer in 2000, a House of Lords Select Committee investigated the science and ethics of the use of hESC and made a number of recommendations [24]. The Select Committee recommended the establishment of a UK oversight body that would monitor and approve the import, export and use of hESC within the UK. The UK Steering Committee for the UK Stem Cell Bank and the Use of Human Stem Cell Lines (the Steering Committee) was established in 2002 under the chairmanship of Lord Patel.
In addition to its oversight functions, it was charged with establishing a code of practice for the use of human stem cell lines and with establishing a UK Stem Cell Bank [25].

\section{The Role of the UK Stem Cell Bank}

Under the auspices of the Steering Committee, the Bank (www.ukstemcellbank.org.uk) was established in 2003 at the National Institute for Biological Standards and Control (NIBSC): an internationally recognised UK government scientific institute experienced in ensuring public health through the standardisation and control of biological products used in medicine (www.nibsc.ac.uk). The Bank, funded by the Medical Research Council (MRC) and the Biotechnology and Biological Sciences Research Council (BBSRC), was charged with:

- establishing well-characterised and reliable stocks of ethically sourced stem cell lines of embryonic, foetal and adult origin and making these available to researchers in the UK and abroad;

- providing seed stocks as starting material for therapeutic use;

- ensuring that the stem cell lines provided by the Bank underwent safety testing to a level commensurate with their intended use;

- demonstrating that the cell banks prepared by the UKSCB were consistent with the characteristics of the cell line as identified by the depositor;

- assessing the characteristic and performance of the cell lines during extended periods of culture, in order to ensure that they retain their suitability for their intended application;

- disseminating performance data relating to the cell lines and developing best practice in their culture, safety testing, characterisation and preservation.

Though the Bank curates stem cell lines and makes these available to the scientific community, the Steering Committee approves all applications to deposit cells in the Bank in order to ensure that these have been ethically sourced with fully informed consent and that the cell lines represent a valuable resource for the biomedical community. All requests for cell lines are treated in a similar manner, with the Steering Committee applying a set of general principles centred on ethical use against which all applications to obtain cells from the Bank are assessed.

\section{Stem Cell Lines for Research and Clinical Therapy}

The requirement to provide cells for both research and clinical therapy has led to the provision of two 'Grades' of cell line by the Bank: 'Research' and 'Clinical'. To date, the Bank has produced no 'Clinical Grade' cells lines since this requires, as a prerequisite, the derivation of the cell line in facilities that comply with EU Good Manufacturing Practice (GMP) or its equivalent [26]. In addition, the implementation in the UK of the EU Tissues and Cells Directive 2004/23/EC [27] (EUTCD) will require that hESC intended for clinical appli- 
cation meet the requirements not only of the parent directive but also of its technical annexes [28, 29].

Within the Bank, the standards applied to the banking of 'Clinical Grade' material are also applied to 'Research Grade' stem cell lines in order to avoid unnecessary duplication. Both can be banked in cleanroom facilities that comply with GMP guidance (including air quality), and 'Research Grade' cell lines are quality-controlled under the same quality system as their 'Clinical Grade' counterparts. The difference lies mainly in the stringent safety testing which will be applied to 'Clinical Grade' cell lines and the requirement under the EUTCD for an appropriate level of donor information for clinical assessment, when the Bank releases a cell line for clinical application.

\section{Curation of Stem Cell Lines}

The establishment of a national stem cell bank was seen as a means to minimise the number of embryos used for stem cell derivation by providing high quality banks of stem cells that would be freely available to the scientific community. To this end, the HFEA introduced changes to its regulations on the use of embryos for research and has required UK laboratories deriving hESC lines to deposit a sample of their line(s) in the Bank as a formal requirement for granting their licence.

It is too early to say what effect the UK Bank and others will have on the number of embryos used for stem cell derivation. Currently the Steering Committee has approved around 60 cell lines from the UK and abroad for deposit in the Bank. Recent estimates put the number of stem cell lines worldwide at approximately 400 [30]: most if not all of which are suitable only for research.

Until recently, there has been little systematic study of these lines under defined conditions to ascertain whether or not cell lines are broadly similar in their properties. Such a study, supported by the UK Stem Cell Bank acting as its technical hub, is currently being completed. This study, undertaken by the International Stem Cell Initiative (www.stemcellforum.org.uk) with expert groups from around the world, aims to characterise a significant number of cell lines (66 cell lines in 17 laboratories worldwide) under defined conditions [31]. If the stem cell lines are shown to be roughly similar in phenotype and, critically, have equivalent capabilities to generate different cell types, the argument for deriving further cell lines for general research applications will not be strong - provided that cell lines can be made freely available through centres such as the UKSCB. However the need for generating new cell lines especially from PGD embryos for the study of genetic diseases and developmental biology will remain.

From a clinical perspective, stem cell lines will be needed for the generation of stable differentiated cells for therapeutic application. These cells will express transplant antigens and will thus need to be sourced from HLA-typed stem cell lines. Though a number of strategies such as somatic cell transfer are being developed to overcome graft rejection, in the inter- im, banks of typed stem cell lines will be needed for transplantation. The question which commonly arises, from a logistical and financial perspective, is what number of cell lines will need to be generated (and banked) in order to provide sufficient HLA diversity of cell lines to provide the maximum benefit for recipients.

A recent paper by Taylor et al. [32] has attempted to establish this, based on data available for organ transplantation. Their findings suggest that as few as 150 consecutive blood groupcompatible donors could provide the maximum practical benefit for HLA matching. This figure takes no account of the overall efficiency of derivation of hESC lines and is highly dependent on a number of extrinsic factors. Calculation is made more difficult by the differing methods of reporting rates of success [33]. Furthermore, cell lines may vary in their capacity to generate the lineage cells required for different therapeutic strategies, thus increasing the required number of HLAmatched stem cell lines.

\section{Cell Banking and Quality Control}

It is well known that cell lines maintained in serial culture are susceptible to genetic variation. The formation of banks of homogeneous cell aliquots can capture a single desired phenotype, allowing researchers to share source material containing functionally identical cells that maintain the desired characteristics; making possible direct comparison between studies performed by different research groups or by single researchers over time.

Additionally, the risk of contamination increase when cell lines are maintained for long periods of time in culture. Cell culture medium will readily support the growth of bacteria and fungi and the routine use of antibiotics to suppress growth may have adverse effects on the cells. While such contamination is often readily identified by the turbidity of the culture medium, more subtle forms of contamination, such as mycoplasma [34] introduced from the environment, viruses introduced via components of the culture medium and even contamination by other cell lines [35], are less readily detected and will affect the properties of the cell. Thus, returning periodically to a well characterised, contamination-free stock of cells reduces the risk of contamination and increases the validity of any results generated from the cell line.

The need for standardisation and quality control of cell banking is recognised [36], and guidance on good cell culture practice (GCCP) is readily available [37]. The UKSCB has adopted a system of banking based on these well-recognised principles [23]. This process of turning a representative sample of a depositor's cell line into a viable stock of cryopreserved cells suitable for distribution to other scientists is shown in figure 2. Unlike primary cell material, such as haematopoietic cells which may undergo limited expansion but are essentially cryopreserved as a single deposit, stem cell lines must be main- 


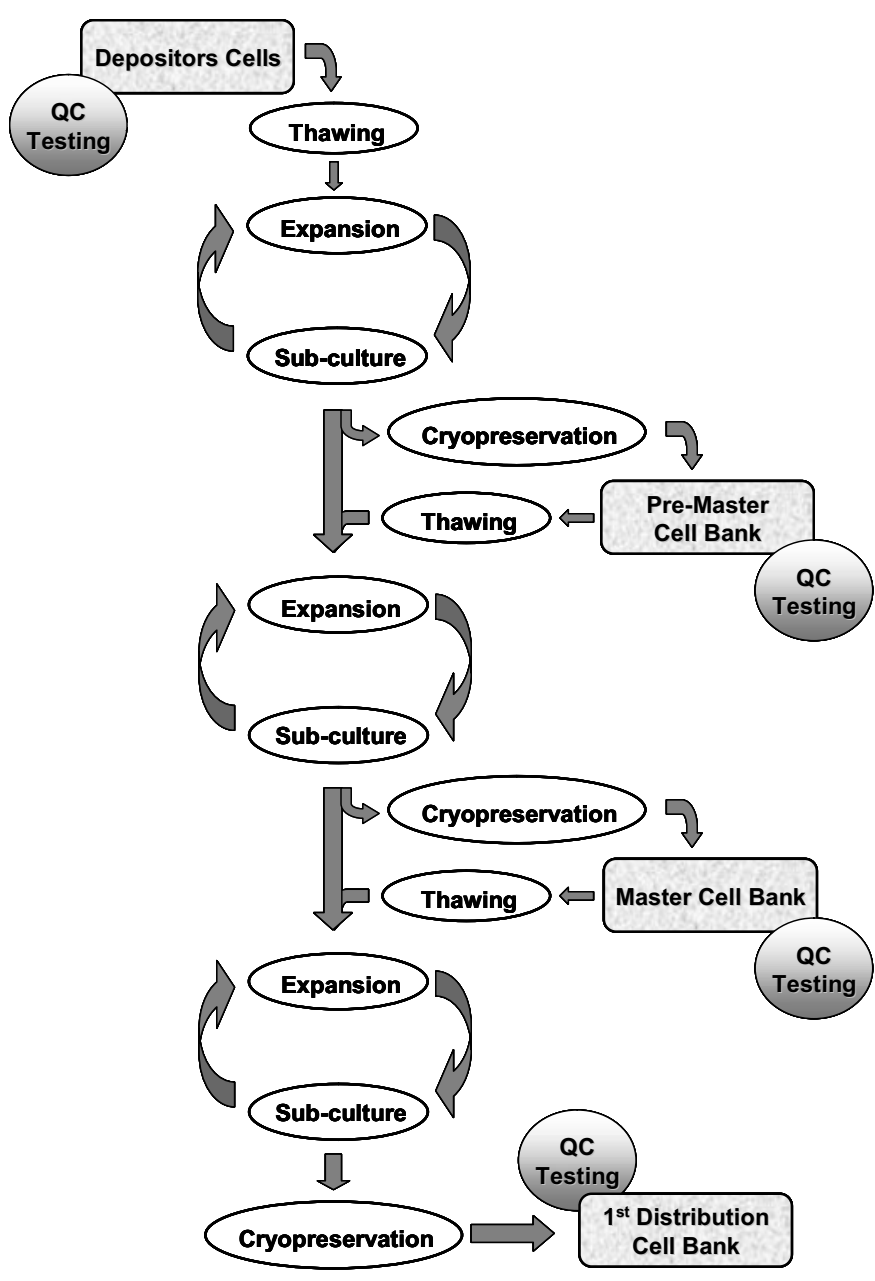

Fig. 2. The process of banking an hESC line [adapted from 23]. Colony numbers are increased through an iterative process until sufficient material has been produced for cryopreservation. The process of moving from one cell bank to another may be continuous, or interrupted by a freeze/thaw cycle with material then taken from the preceding bank. Once the first DCB is exhausted, a new DCB will be prepared from cells of the MCB.

tained in culture for many weeks (anywhere between 8 and 26 weeks) in order to generate the cell numbers required for a cell bank. In brief, three banks of cells are prepared sequentially through an iterative process of growth and sub-culture (passage) to expand the initial population of stem cells.

From the initial cryopreserved material supplied by the depositor a small bank of cells is prepared which is designated the Pre-Master Bank (PMB). This provides the cells that are used for the initial sterility tests and quality control studies to establish the characteristics of the cell line at the time of deposit. If sufficient frozen stocks from a single culture are available from the depositor, these can be designated as the PMB. Material from this bank will also be cryopreserved as a long-term archive. An aliquot or aliquots from this bank will then be used to establish the Master Cell Bank (MCB).
The MCB represents the stock of cryopreserved cell aliquots that will be the reference point for all future work undertaken with that cell line. As such, it will undergo extensive characterisation and quality control testing. This may include cytogenetics, DNA profiling, isoenzyme analysis, morphological assessment and analysis of surface and other recognised molecular markers. Measurement of growth characteristics, viability and functional assessments together with sterility tests for microbial and mycoplasma contamination and tests for viral contamination will also form part of the release process. The MCB will be the bank from which all future cell banks will be prepared. Stock from the MCB is not distributed so that, while the MCB exists, there will always be a bank of cells with known characteristics at the same passage level from which cell banks for distribution may be prepared.

The Distribution (or working) Cell Bank (DCB) is a large bank of cells prepared from a single or limited number of ampoules of the MCB. Stock from this bank is distributed and used for experimental or manufacturing purposes. This bank too will undergo extensive testing to ensure its comparability with both the PMB and MCB. Once this bank has been exhausted, a fresh DCB can be prepared from material within the MCB. This tiered approach to banking ensures that cells from the same passage level are available over many decades.

\section{Culture of Human Embryonic Stem Cells}

The process of cell culture of hESC lines shares many of the principles of routine cell culture. However, a number of significant differences exist, not only between hESC lines and somatic cells (including somatic stem cells) but also between hESC and other mammalian ESC. Some of these differences are influential in the current problems associated with their cryopreservation.

ESC are grown on a feeder layer of mitotically inactive fibroblasts. In the case of mESC and primate ESC lines, these are generally low passage cultures derived from mouse embryos or continuous mouse fibroblast cell lines. This is also true for routine culture of hESC lines suitable for research; though human mitotically inactive feeder cells [38], have been introduced as a consequence of the drive towards the production of 'Clinical Grade' cell lines suitable for therapeutic use. This also includes the development of serum-free [39] and even feeder-free systems [40].

Primary cells and mammalian cell lines may be cultured either as single cell suspensions or as adherent cell monolayers depending on cell type. Many systems exist for the propagation and expansion of these cells, including automated systems such as bioreactors and multiwell formats as well as the traditional culture dish and flask. Adult human mesenchymal stem cells, whether derived from bone marrow [41] or from sources such as umbilical cord [42] also grow as adherent monolayers of unassociated cells. However, human (and animal) ESC will 

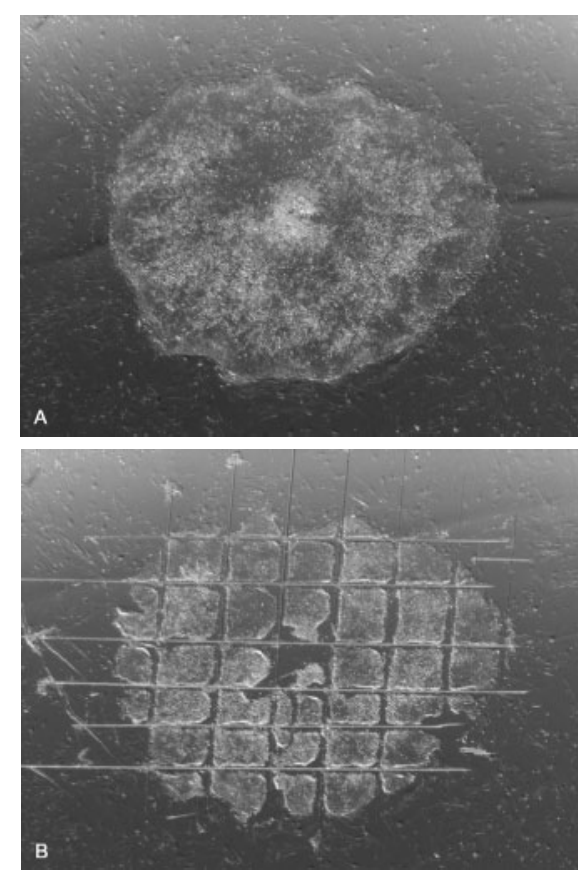

Fig. 3. Mechanical dissection of a hESC colony. Colony size varies. Typically, each colony contains around 30,000-50,000 cells. Differentiated cells at the edge of the colony will be removed prior to dissection. The colony is dissected by horizontal and vertical cuts into small clumps (generally of between 500-1,000 cells) using a cutting tool. The clumps or clusters are then transferred to a capillary and placed in medium prior to passaging or cryopreservation.

(Photographs courtesy of $P$.

Timmons, copyright NIBSC)
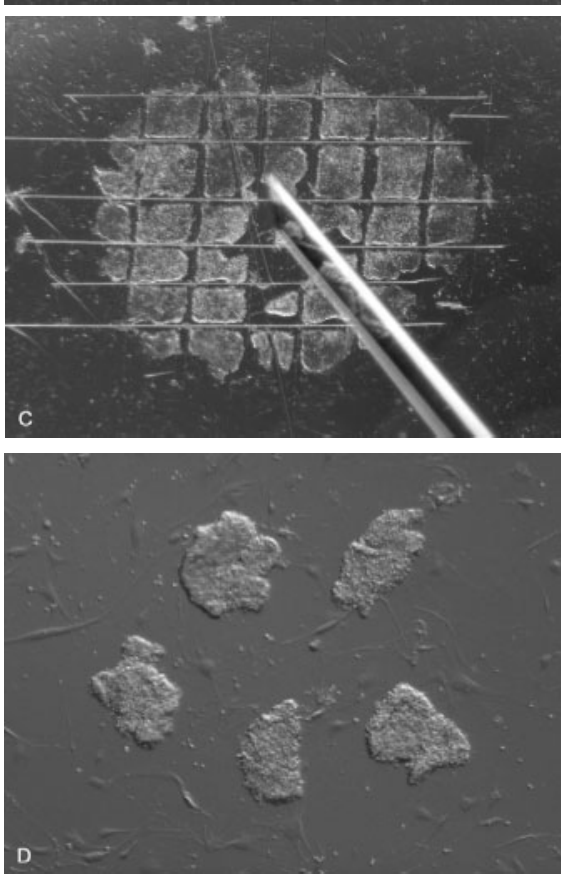

In contrast, $\mathrm{hESC}$ (and primate ESC) cannot currently be passaged or cryopreserved as single cells. Primate stem cells show an extremely low plating efficiency if dissociated to single cells [44] while re-plating $\mathrm{hESC}$ as a single cell suspension leads to differentiation or cell death. Optimum cell cluster size for cryopreservation has been reported to be of the order of 100-500 cells [45] though experimental evidence is sparse. The requirement to cryopreserve hESC as colony fragments has had a significant effect on the method generally adopted for hESC cryopreservation.

To maintain cell-cell contact and an optimum cluster size, hESC are sub-cultured by mechanical dissection (fig. 3). This is the primary method for passaging hESC lines; at least in the early stages of establishing the cell lines in culture. Enzymic dissociation is employed for many cell lines [17] but necessitates strict control of the process in order to prevent dispersal to a single cell suspension. In order to passage hESC by mechanical dissection, the colonies must be grown in culture dishes or multiwell plates. Such processing is undesirable for 'Clinical Grade' cells as it is defined as an open-process under the current regulatory framework and strict levels of air quality are imposed on such processes. This too impacts on cryopreservation, as the labour-intensive nature of the process and the necessity to undertake processing within a cleanroom environment poses additional logistical problems.

\section{Cryopreservation of Human Embryonic Stem Cells}

Two approaches to cryopreservation of hESC have been adopted. As with most cells and tissues, including haematopoietic stem cells, initial studies have been empirical and based largely on the application of methods successfully applied to other, apparently closely related, cells. Two 'candidates' for this role have been the mESC and the embryo. This has led to the development of protocols for hESC lines that use either conventional freezing or vitrification. Their application has focussed on the need to maintain a working stock of stem cells rather than on investigating and understanding the problem of cryopreservation per se.

\section{Cryopreservation by Slow Cooling}

Cryopreservation of hESC lines by slow cooling is based on well-established protocols developed for mESC [46]. In turn, these were adapted from protocols used for cultured cells: both primary cells and continuous cell lines. For mESC, the colonies are first dissociated enzymically into a single cell suspension. This is followed by exposure of the cells to the CPA solution: generally comprised of $5-20 \%$ dimethyl sulfoxide (DMSO) in culture medium supplemented with foetal calf serum. A number of protocols have adopted the use of passive cooling devices deployed in a $-80{ }^{\circ} \mathrm{C}$ mechanical refrigerator; though controlled-rate cooling, generally at cooling rates of the order of $1-2{ }^{\circ} \mathrm{C} / \mathrm{min}$, has also been employed. Cells are 
frozen in cryovials, though variations to this have involved the freezing of cells in situ in multi-well plates with storage at $-80{ }^{\circ} \mathrm{C}[47,48]$. Typically, rates of recovery after rapid thawing have been in excess of $90 \%$, with the surviving cells producing undifferentiated colonies when cultured.

For hESC, which must be cryopreserved as cell clusters, applying slow cooling protocols that are effective for mESC has met with notable failures [49]. In an early study, using a standard slow cooling protocol, Reubinoff et al. [50] reported $16 \%$ recovery after freezing and thawing (as measured by the number of colonies recovered 2 weeks after thawing). The colonies recovered were undersized compared to typical hESC colonies and showed a significant degree of differentiation. Zhou et al. [51] also reported similar results with only slightly higher recovery (approximately 23\%, based on the number of colonies recovered at day 9, post thaw). Again, the rate of growth of the surviving colonies was reduced, while the level of differentiation in the surviving colonies was higher than that in a comparable, non-cryopreserved group. Both studies utilised 10\% DMSO as the CPA. A study by Ha et al. [52] compared glycerol and ethylene glycol (EG) to DMSO, either on their own or in combination with DMSO. The results indicated that, even with the most favourable combination (5\% DMSO combined with $10 \%$ EG in $50 \%$ foetal bovine serum), recovery was limited to just $30 \%$. In these limited studies, passive cooling devices were used in which there was little or no attempt to control (or record) cooling rate. A study using controlled-rate cooling produced similar results. Richards et al. [53] compared the ability of a 'conventional freezing medium' to protect hESC during controlled-rate cooling at $1{ }^{\circ} \mathrm{C} / \mathrm{min}$. The cooling rate was only controlled as far as $-30{ }^{\circ} \mathrm{C}$ before the samples were plunged into liquid nitrogen. Though it may be argued that this is too high a temperature, even with a 5-min equilibration period, to initiate the plunge into liquid nitrogen, controlled-rate cooling produced no better post-thaw recovery than the previous studies.

\section{The 'Co-Operative' Stem Cell}

It has been speculated that the basis for this disparity between the post-thaw recovery of mESC and hESC following slow cooling lies in the 'highly co-operative' nature of hESC. The requirement to passage and cryopreserve hESC as clusters rather than single cells has been pointed to as evidence for this, as have several studies which have shown that paracrine signalling between hESC is essential for survival and maintenance of the undifferentiated state $[3,4,45]$. Gap junctions have been implicated in the control of a number of cellular processes, including cell proliferation, differentiation and apoptosis $[54,55]$, and the presence of functional gap junctions in hESC $[56,57]$ has added weight to this speculation.

\section{Damage during Slow Cooling}

However, undifferentiated mESC also express gap junction proteins such as connexin 43 and 45, and gap junctions have been demonstrated by electron microscopy in these cells [58,
59], yet mESC survive passage and slow cooling as a single cell suspension with little difficulty. The difference may therefore lie, not in the presence of gap junctions during colony growth and cell proliferation, but in their continued presence within the cell clusters during slow cooling. Cell-to-cell propagation of intracellular ice has been demonstrated in a number of cells and tissues, including cultured cell monolayers [60] and cell strands from insect salivary glands [61]. Berger and Urik [61] proposed that intracellular ice can propagate between adjacent cells via gap junctions, and Acker et al. [62] have argued that this theory could explain the experimental results they obtained in their study comparing ice propagation in MDCK (gap junction-forming) and V-79W (non-gap junction-forming) cell monolayers. They observed a significant difference in the formation and propagation of intracellular ice in confluent monolayers with and without gap junctions.

The observation that intracellular ice propagates more readily between cells with gap junctions under certain conditions may at least in part explain the poor recovery of hESC after slow cooling. Damage to the hESC clusters caused by intercellular ice propagation, either by random nucleation events within the cluster and propagation through the gap junctions $[62,63]$ or from surface-catalysed nucleation at its periphery followed by cell-to-cell propagation $[64,65]$, could lead to disruption of the cell cluster, affecting both cell proliferation, differentiation and apoptosis on thawing.

Ji et al. [66] have demonstrated increased survival on the application of slow-cooling protocols to adherent hESC colonies or intact colonies embedded in a soluble basement membrane matrix. Pre-loading the cells with trehalose for 1-2 days before cryopreservation further enhanced survival. Recently, Heng et al. [67] postulated that the loss of viability seen with intact and adherent hESC colonies was due to an apoptotic mechanism arising from sub-lethal cryoinjury, rather than a mechanism of cellular necrosis that might be inferred from the results of Ji et al. [66]. They reported that the majority of hESC expressed a key mediator of apoptosis in mammalian cells, caspase-3, within $90 \mathrm{~min}$ of thawing when cells were maintained in culture at $37^{\circ} \mathrm{C}$. Their hypothesis has been lent weight by the demonstration that the rate of cell death could be reversibly slowed by storage of the cells at $4{ }^{\circ} \mathrm{C}$ [68].

A number of recent studies have indicated that increased levels of survival may be obtained by seeding. Ware et al. [69] investigated the effect of seeding on the survival of hESC after thawing. Survival was calculated as combined colony numbercolony size, relative to a pre-freeze control. Clusters were frozen by controlled-rate cooling in $10 \%$ DMSO at cooling rates between 0.3 and $3{ }^{\circ} \mathrm{C} / \mathrm{min}$. High survival ( $\left.~ 80 \%\right)$ was obtained at cooling rates below $1.8^{\circ} \mathrm{C} / \mathrm{min}$, but only if the samples were seeded. The effect of seeding temperature on survival was not fully investigated: seeding at -7 and $-10{ }^{\circ} \mathrm{C}$ produced similar results. Yang et al. [70] have reported similar results in a series of recent reports with seeding at $-10{ }^{\circ} \mathrm{C}$ and a cooling rate of $0.5^{\circ} \mathrm{C} / \mathrm{min}$. Improved survival under these con- 
ditions may reflect a reduction in the extent of intercellular ice propagation in the cell clusters as ice is preferentially nucleated in the surrounding extracellular medium.

\section{Cryopreservation by Vitrification}

Despite these recent studies, the majority of groups deriving stem cell lines have adopted vitrification as the method of choice despite practical difficulties associated with this methodology. Vitrification is the solidification of a liquid without crystallisation and the growth of ice. This is achieved when solutes in the system are sufficiently concentrated, or the system cooled sufficiently rapidly, that the increased viscosity inhibits nucleation and prevents the growth of ice. As cooling continues, viscosity continues to increase until all molecular motion is (for all practical purposes) halted and the solution becomes a glass. In this condition, the system displays the properties of a solid but retains the molecular structure of a liquid.

Vitrification can be approached either from the direction of increasing the solute concentration to levels sufficient to avoid ice formation whatever the cooling rate, or by employing sufficiently high cooling rates to prevent ice nucleating. However this produces a metastable state that can lead to devitrification (and ice crystallisation) on rewarming. Though this poses serious risks of cell damage, this approach has been applied successfully to many tissues and cells, including ova and embryos [71-73].

The adoption of vitrification as the predominant method of cryopreservation for hESC is largely due to comparative studies by three groups, two of which indicated rates of recovery of undifferentiated colonies of $>75 \%$ for vitrified hESC compared to $\sim 5 \%$ after slow cooling $[50,51,53]$. The vitrification protocols reported in these studies are very similar, based as they are on one developed for bovine ova and embryos [74] and modified by Reubinoff et al. [50] for application to hESC. The method has since been described in a manual on hESC culture produced by ESI International and is available via their website (www.escellinternational.com). It has also been described in detail with minor modifications elsewhere [39, 75].

In essence, this protocol requires the stepwise exposure of hESC colony fragments to two vitrification solutions of increasing CPA concentration, the common components of which are DMSO and EG. The composition of the vehicle solution varies, with differences in sucrose concentration, the presence or absence of serum and the buffer used. Colony fragments are exposed to the two vitrification solutions sequentially. Exposure to the vitrification solutions is brief ( $60 \mathrm{~s}$ and $25 \mathrm{~s}$ respectively at either room temperature or $37^{\circ} \mathrm{C}$ ). No studies have so far been conducted to determine either the permeability of the cells (or the colony fragments) to CPA or the intrinsic toxicity of these components to hESC; though exposure to DMSO is known to induce differentiation in ESC and EC cells [76].

To achieve vitrification using these solutions, rapid cooling is required. This has been achieved by the use of an open pulled straw (OPS) and direct immersion in liquid nitrogen. This method, developed by Vajta et al. [74, 77] for bovine embryos, uses a finely draw capillary with a diameter that permits a volume of $\sim 20 \mu$ to be drawn into the straw by capillarity. When directly immersed in liquid nitrogen, cooling rates reported to be of the order of $20,000{ }^{\circ} \mathrm{C} / \mathrm{min}$ are achieved [74, 77]. Straws are then generally transferred under liquid nitrogen (to avoid devitrification) to liquid-phase nitrogen storage.

To avoid ice crystallisation during thawing, the straws are rewarmed as rapidly as possible by direct immersion of the tip of the loaded straw into pre-warmed culture medium containing sucrose. Once thawed the colony fragments are then expelled into this medium and transferred stepwise through CPA washout solutions, containing decreasing concentration of sucrose as the osmotic buffer, until they are plated into culture medium. An alternative method with direct exposure to growth medium without stepwise elution of the CPAs has also been used with no noticeable deleterious effects [75].

The vitrification method, while capable of producing relatively high recovery of colony fragments that in turn form undifferentiated colonies, is technically challenging. There are anecdotal reports of substantially lower recoveries (both in terms of colony fragments recovered post thaw and the levels of differentiation in those fragments that produced viable colonies) than those reported in the literature. Even the original paper by Reubinoff et al. [50] reported $<30 \%$ recovery of undifferentiated colonies. The method also poses problems from a microbiological and logistical perspective.

\section{Logistical and Microbiological Problems Associated with Vitrification}

The use of very narrow bore, open pulled straws plunged directly into liquid nitrogen has been thought necessary in order to produce the cooling rates required for vitrification in the chosen CPA. However, there is an increased risk of microbiological contamination using the OPS method. The transmission of infections through IVF routes has been the subject of debate [78, 79], and much of this is relevant to hESC lines. Moreover, transmission of infection associated with direct exposure to liquid nitrogen has been the source of a number of reports from both laboratory and clinical studies [80, 81]. The use of open straws during vitrification followed by their storage under liquid nitrogen is unlikely to be tolerated by regulatory agencies for 'Clinical Grade' hESC lines due to the potential for contamination of the sample and the transmission of disease.

The use of a larger, sterile sealed straw that protects the contents from non-sterile liquid nitrogen has been investigated by Richards et al. [53]. They showed that successful vitrification of hESC colony fragments was possible using sample volumes equivalent to those used in the OPS method. Recently, successful vitrification has been reported for mouse embryos using a straw-in-straw method [82, 83]. This method, equiva- 
lent to double bagging, has not yet been applied to either human embryos or hESC.

Logistically, it is difficult to see the existing method being applied outside of a laboratory setting. Even with improvements such as those described above, the process is difficult to apply to bulk quantities of hESC. At the UK Stem Cell Bank, cell banks of 100-200 straws are prepared. Typically, each straw will hold 8-12 colony fragments which must be prepared, transferred through the vitrification solutions, loaded into a straw and plunged into liquid nitrogen. The process is extremely labour-intensive and operator-dependent, and, with exposure times to the vitrification solution so short, it is difficult to eliminate variability. At the same time, the use of straws, while capable of being applied to banks of the size produced by the UKSCB, would make automating the process technically challenging.

\section{Storage and Transportation}

Cryopreserved banks of hESC lines will need to be maintained over many years, and this will require long-term storage at temperatures below the glass transition. This is especially true for vitrified material where there is the need to avoid the damaging effects of devitrification and ice crystal growth. In the case of gametes and embryos, and now hESC, this has been effected through the storage of samples in the liquid phase of nitrogen. Storage in liquid phase has been brought into question since an outbreak of hepatitis B amongst autologous bone marrow recipients was traced to a contaminated liquid nitrogen storage refrigerator [82]. This led to the recommendation from a UK Department of Health advisory group that storage of cells for clinical use was 'safer' in the vapour (or more accurately, gas) phase above liquid nitrogen than in the liquid phase itself [83]. Though this recommendation applied only to blood stem cells, it has nevertheless been applied to other cells and tissues, and storage in vapour phase has been suggested for gametes and embryos [79].

Whilst this is not a substantial problem for most material cryopreserved by conventional slow cooling, the existence of significant vertical temperature gradients in vapour-phase liquid nitrogen storage vessels has been seen as a significant risk for the storage of vitrified material and the driving force for the continued storage of such samples in the liquid phase of liquid nitrogen. However, the use of thermally conducting materials such as aluminium racking systems, and the use of heat shunts within liquid nitrogen storage vessels has been shown to drastically reduce such temperature gradients within the vessels so that temperatures below at least $-160{ }^{\circ} \mathrm{C}$ are easily obtainable $[84,85]$. The introduction of so-called 'isothermal' or 'dry' vessels, which have liquid nitrogen-jacketed storage compartments, has also made storage in the vapour phase more straightforward, and many cell and tissue banks, including the UK Stem Cell Bank, have now moved to vapour phase storage to reduce the risk of cross-contamination of stored material.

A significant disadvantage of employing vitrification is the need to transport vitrified material at temperatures below the devitrification temperature. This precludes the use of solid $\mathrm{CO}_{2}$ (dry ice) for vitrified hESC and necessitates the use of costly dry shippers that maintain the temperature at $-196{ }^{\circ} \mathrm{C}$ during transportation.

\section{Requirements for Improved Cryopreservation}

The current method of vitrification adopted for hESC, while generally producing satisfactory levels of recovery, poses significant logistical problems, and the use of straws restricts it to small-scale cell banking. Scaling up to even modest volumes will require different technical solutions. Heng et al. [86] have proposed one such solution: a novel plate design for the cryopreservation of adherent colonies. However, its use, or even the use of cryovials or bags, will require vitrification solutions capable of vitrifying at far lower cooling rates than those currently applied through direct immersion in liquid nitrogen. Strategies for this and the avoidance of devitrification have been discussed elsewhere [72]. One such strategy, the replacement of high concentrations of permeating CPAs by polymers to reduce cellular toxicity, have been successfully applied to embryos [87], but there are no studies so far that address CPA toxicity in hESC.

Slow cooling has fewer logistical problems but in many cases produces low levels of recovery and significant levels of differentiation in cells surviving the thawing process. The addition of sugars such as trehalose or extracellular matrix proteins such as collagen and laminin $[88,89]$ have been shown to produce modest improvements in recovery of colony fragments and reduce the levels of cellular differentiation post thaw, but studies that adopt a methodological approach to the study of the cryobiological variables that influence the cryopreservation process are lacking.

One such methodological approach has been used successfully for platelets and cord blood stem cells [90-92]. In such an approach to optimising cryopreservation protocols, the effect of osmotic stress is first decoupled from CPA toxicity. Then 'safe' addition and elution protocols are modeled, based on the data of membrane permeability to water and CPA, before the effect of CPA toxicity is investigated. Finally, using safe addition/elution protocols with tolerated concentrations of CPA, the effects of cooling and warming rate can be investigated and an optimised protocol generated [93]. Such an approach is applicable not only to cryopreservation by slow cooling but also to vitrification since the initial steps in the process can be applied to many of the components of vitrification solutions.

A prerequisite for any study is a method for assessing the 'viability' of the cell after the cryopreservation process. This can 
be a membrane integrity test, metabolic assay, measurement of the cell's or tissue's ability to carry out its function or a combination of these [94]. For instance, studies on umbilical cord blood stem cells have employed a flow cytometric membrane integrity assay of the CD34+ cell population in conjunction with a clonogenic assay assessing the effects of cryopreservation [95].

At present hESC must be cryopreserved as cell clusters of undefined size rather than single cells. This complicates the use of assay that rely on single cell suspensions to quantitate postthaw survival (e.g. trypan blue, 7-AAD), especially where the assay is normalised to pre-freeze controls. Once thawed, the clusters must attach to the culture vessel, before they can begin to divide as undifferentiated stem cells, which retain their pluripotent capacity as well as their ability to differentiate when the right conditions are applied. Metabolic assays such as MTT and Alamar blue are complicated by the presence of the fibroblast feeder layer required for ESC growth and the fact that exposure for even short periods of time to solutions other than the culture medium can lead to spontaneous differentiation of the colony.

Following cryopreservation some clusters will disaggregate, either partially or completely. More will remain in suspension unable to attach but showing 'viable' cells on assessment by membrane integrity test, whilst others will attach and partially differentiate. Even those colonies that attach without differentiating often experience an extended phase when little cell division takes place and the colony fragment, though attached and still 'viable', does not expand in size. This makes calculations of cell doubling time impractical as this period may extend over a number of weeks, well beyond the life of a typical cell culture experiment.

The use of pluripotency markers such as Oct4 as functional criteria is also problematic. A recent study on the effect of cryopreservation on this transcription factor suggested a loss of pluripotency following slow cooling [96]. However, since the study utilised a PCR method requiring cell lysate to detect the marker, it was not possible to establish whether this was indeed the case or whether there had been a transient downregulation of gene expression.

\section{Conclusion}

The goal of producing cellular therapies and tissue-engineered products based on hESC will require solving many technical, microbiological and regulatory challenges [97, 98]. Regulatory authorities will require not only ethically sourced stem cell lines but also appropriate donor selection and screening protocols. Facilities not only for cell banking but also for cell line derivation will need to comply with strict regulatory guidelines. Cell lines will require levels of microbiological safety and quality control comparable to other cell and tissue grafts. Animal-based components within the culture process and xenogeneic feeders will have to be eliminated, and methods for cell expansion and cell differentiation enhanced to produce the quantities of cells necessary for therapeutic use. Within this context cryopreservation is but a small part, and future routes for the development of cryopreservation processes will depend on the methods developed for scale-up and expansion of hESC. However the banking of seed stocks such as those prepared by the UK Stem Cell Bank, and the larger stocks needed for the production of cellular therapies and tissue-engineered products, will require a sound understanding of the effect of cryobiological variables as they apply to the hESC lines if optimised cryopreservation protocols are to be established for this important resource.

\section{Acknowledgements.}

I would like to thank the staff of the UKSCB especially Lesley Young and Lyn Healy and also Glyn Stacey for their help in preparing this review.

\section{References}

1 Evans MJ, Kaufman M: Establishment in culture of pluripotent cells from mouse embryos. Nature 1981;292:154-156.

2 Bongso A, Fong C-Y, Ng SC, Ratnam S: Isolation and culture of inner mass cells from human blastocysts. Hum Reprod 1994;9:2110-2117.

3 Thomson J, Itskovitz-Eldor J, Shapiro, SS, Waknitz MA, Swiergeil JJ, Marshall VS, Jones JM: Embryonic stem cell lines derived from human blastocysts. Science 1998;282:1145-1147.

$\checkmark 4$ Reubinoff BE, Pera MF, Fong C-Y, Trounson A, Bongso A: Embryonic stem cell lines from human blastocyts: somatic differentiation in vitro. Nature Biotechnology 2000;18:399-404.

5 Thompson H: Bioprocessing of embryonic stem cells for drug discovery. Trends Biotechnol DOI: 10.1016/.tibtech.2007.03.003.

6 6 Lerou PH, Daley GQ: Therapeutic potential of embryonic stem cells. Blood Rev 2005;19:321-331.
7 Cohen S, Leshanski L, Itskovitz-Eldor J: Tissue engineering using human embryonic stem cells. Methods Enzymol 2006;420:303-315.

8 Strulovici Y, Leopold PL, O'Connor TP, Pergolizzi RG, Crystal RG: Human embryonic stem cells and gene therapy. Mol Therapy DOI:10.1038/mt.sj. 6300125 .

9 Zhang S-C, Li X-J, Johnson MA, Pankratz MT: Human embryonic stem cells for brain repair. Phil Trans R Soc B DOI:10.1098/rstb.2006.2014.

10 Fukuda H,Takahashi J: Embryonic stem cells as a cell source for treating Parkinson's disease. Exp Opin Biol Ther 2005;5:1273-1280.

11 Heit JJ, Kim SK: Embryonic stem cells and islet replacement in diabetes mellitus. Ped Diabetes 2004; 5:5-15.

12 Caspi O, Gepstein L: Regenerating the heart using human embryonic stem cells - from cell to bedside. IMAJ 2006;8:208-214.
13 Bhatia M: Hematopoiesis from human embryonic stem cells. Annals N Y Acad Sci DOI: 10.1196/annals.1392.007.

14 Smith AG: Embryo-derived stem cells: of mice and men. Annu Rev Cell Dev Biol 2001;17:435-462.

15 Henderson JK, Draper JS, Baille HS, Fishel S, Thompson JA, Moore H, Andrews PW: Preimplantation human embryos and embryonic stem cells show comparable expression of stage-specific embryonic antigens. Stem Cells 2002;20:329-337.

16 Hoffman LM, Carpenter MK: Characterisation and culture of human embryonic stem cells. Nature Biotechnol 2005;23:699-708.

17 Cowan CC, Klimanskaya I, McMahon J, Atienza J, Witmyer J, Zucker JP, Wang S, Morton CC, McMahon AP, Powers D, Melton DA: Derivation of embryonic stem-cell lines from human blastocysts. N Engl J Med 2004;350:1353-1356. 
18 Pickering SJ, Braude PR, Patel M, Burns CJ, Trussler J, Bolton V, Minger S: Preimplantation genetic diagnosis as a novel source of embryos for stem cell research. Reprod Biomed Online 2003;7:353-364.

19 Strelchenko N, Verlinsky O, Kukharenko V, Verlinsky Y: Morula-derived human embryonic stem cells. Reprod Biomed Online 2004;9:623-629.

20 Zhang X, Stojkovic P, Przyborski S, Cooke M, Armstrong L, Lako M, Stojkovic M: Derivation of human embryonic stem cell lines from developing and arrested embryos. Stem Cells 2006;24:26692676.

21 Klimanskaya I, Chung Y, Becker S, Lu SJ, Lanza R Human embryonic stem cell lines derived from single blastomeres. Nature 2006;444:481-485.

22 Bongso A, Tan S: Human blastocyst culture and derivation of embryonic stem cell lines. Stem Cell Rev 2005;1:87-98.

23 Healy L, Hunt C, Young L, Stacey G: The UK Stem Cell Bank: its role as a public research resource centre providing access to well-characterised seed stocks of human stem cell lines. Adv Drug Del Rev 2007;57:1981-1988.

24 House of Lords Stem Cell Research Select Committee: Stem cell research - report. 2002. www.parliament.the-stationery-office.co.uk/pa/ld200102/ldselect/ldstem/83/8301.htm.

25 Medical Research Council: Code of practice for the use of human stem cell lines. 2006. www.mrc.ac.uk Utilities/Documentrecord/index.htm?d $=M R C$ 003132

26 Medicines and Healthcare Regulatory Agency (MHRA): Rules and Guidance for Pharmaceutica Manufacturers and Distributors 2007. London, Pharmaceutical Press, 2007.

27 EU Directive 2004/23/EC: On setting standards of quality and safety for the donation, procurement, testing, processing, preservation, storage and distribution of human tissues and cells. http://eur-lex. europa.eu/LexUriServ/site/en/oj/2004/l_102/l_ 10220040407 en00480058.pdf.

28 EU Directive 2006/17/EC: Implementing Directive 2004/23/EC of the European Parliament and the Council as regards certain technical requirements for the donation, procurement, and testing of human tissues and cells. http://eur-lex.europa.eu LexUriServ/site/en/oj/2006/l_038/l_03820060209en 00400052.pdf.

29 EU Directive 2006/86/EC: Implementing Directive 2004/23/EC of the European Parliament and the Council as regards traceability requirements, notification of serious adverse reactions and events and certain technical requirements for the coding, processing, preservation, storage and distribution of human tissues and cells. http://eur-lex.europa.eu/ LexUriServ/site/en/oj/2006/l_294/l_29420061025en0 0320050.pdf.

-30 Guhr A, Kurtz A, Freidgen K, Loser P: Current state of human embryonic stem cell research: an overview of cell lines and their use in experimental work. Stem Cells 2006;24:2187-2191.

31 The Steering Committee for The International Stem Cell Initiative: The International Stem Cell Initiative: towards benchmarks for human embryonic stem cell research. Nature Biotech 2005;23: 795-797.

\$2 Taylor CT, Bolton EM, Pocock S, Sharples LD, Pedersen RA, Bradley A: Banking on human embryonic stem cells: estimating the number of donor cell lines needed for HLA matching. Lancet 2005; 366:2019-2025.

33 Stojkovic M, Lako M, Strachen T, Murdoch A: Derivation, growth and applications of human embryonic stem cells. Reproduction 2005;128:259-267.
34 Drexler HG, Uphoff CC: Mycoplasma contamination of cell cultures. Incidence, sources, effects, detection, elimination, prevention. Cytotechnology 2002;39:75-90

35 MacLeod RA, Dirks WG, Matsuo Y, Kaufman M, Milch H, Drexler HG: Widespread intraspecies cross-contamination of human tumor cell lines arising at source. Int J Cancer 1999;83:555-563.

36 Stacey G: Fundamental issues for cell-line banks in biotechnology and regulatory affairs; in Fuller BJ, Lane N, Benson EE (eds): Life in the Frozen State. London, CRC Press, 2004, pp 437-452.

37 Sandra C, Balls M, Bowe G, Davies J, Gstraunthaler G, Hartung T, Hay R, Merten OW, Price A, Schechtman L, Stacey G, Stokes W, Patlewicz G: Guidance on good cell culture practice. a report of the second ECVAM task force on good cell culture practice. Altern Lab Anim 2005;33:261-287.

38 Lee JB, Song JM, Lee JE, Park JH, Kim SJ, Kang SM, Kwon JN, Kim MK, Roh SI, Yoon HS: Available human feeder cells for the maintenance of human embryonic stem cells. Reproduction 2004; 128:727-735.

39 Pera MF, Laslett A, Hawes SM, Tellis I, Koh K, Nguyen L: Isolation and characterisation of human ES cells; in Notarianni E, Evans MJ (eds): Embryonic Stem Cells. A Practical Approach, Oxford, Oxford University Press, 2006, pp 238-259.

40 Amit M, Itskovitz-Elder J: Feeder-free culture of human embryonic stem cells. Methods Enzymol 2006;420:37-49.

41 Pittenger MF, Mbalaviele G, Black M, Mosca JD and Marshak DR: Mesenchymal stem cells; in Koeller MR, Palssen BO, Masters JRW (eds): Human Cell Culture. Vol V. Primary Mesenchymal Cells. London, Kluwer, 2001, pp 189-207.

42 Sarugaser R, Lickorish D, Baksh D, Hosseini MM, Davies JE: Human umbilical cord perivascular (HUCPV) cells: a source of mesenchymal progenitors. Stem Cells 2005;23:220-229.

43 Brook FA: Procedures for deriving ES cell lines from the mouse; in Notarianni E, Evans MJ (eds): Embryonic Stem Cells. A Practical Approach. Oxford, Oxford University Press, 2006, pp 7-40.

44 Suemori H, Sasai Y, Umenda K, Nakatsuji N: ES cell lines from the cynomologus monkey (Macaca Fasicularis); in Notarianni E, Evans MJ (ed): Embryonic Stem Cells. A Practical Approach. Oxford, Oxford University Press, 2006, pp 294-319.

45 Amit M, Carpenter MK, Inokuma MS, Chiu CP, Harris CP, Waknitz MA, Itskovitz-Eldor J, Thomon JA: Clonally derived human embryonic stem cell lines maintain pluripotancy and proliferative potential for prolonged periods of culture. Dev Biol 2000;227:271-278.

46 Udy GB, Evans MJ: Microplate DNA preparation, PCR screening and cell freezing for gene targeting in embryonic stem cells. Biotechniques 1994;17: 887-894.

47 Robertson EJ: Embryo derived cell lines, in Robertson EJ (ed): Teratocarcinomas and Embryonic Stem Cells: A Practical Approach. Oxford, IRL Press, 1987, pp 71-112.

48 Ure JM, Fiering S, Smith AG: A rapid and efficient method for freezing and recovering clones of embryonic stem cells. Trends Genet 1992;8:6.

49 Heng BC, Kuleshova LL, Bested SM, Liu H, Cao T: The cryopreservation of human embryonic stem cells. Biotechnol Appl Biochem 2005;41:97-104.

50 Reubinoff BE, Pera MF, Vajta G, Trounson AO: Effective cryopreservation of human embryonic stem cells by the open pulled straw vitrification method. Human Reprod 2001;16:2187-2194.
51 Zhou CQ, Mai QY, Li T, Zhaung GJ: Cryopreservation of human embryonic stem cells by vitrification. Chin Med J (Engl) 2004;117:1050-1055.

52 Ha YS, Jee BC, Suh CS, Kim HS, Oh SY, Kim AH, Moon SY: Cryopreservation of human embryonic stem cells without the use of a programmable freezer. Human Reprod 2005;20:1779-1785.

53 Richards M, Fong CY, Tan S, Chan WK, Bongso A: An efficient and safe xeno-free cryopreservation method for the storage of human embryonic stem cells. Stem Cells 2004;22:779-789.

54 Simon AM, Goodenough DA: Diverse functions of vertebrate gap junctions. Trends Cell Biol 1998;8 477-483.

55 De Maio A, Vega VL, Contreras JE: Gap junctions, homeostasis and injury. J Cell Physiol 2002;191: 269-282.

56 Sathananthan H, Pera M, Trounson A: The fine structure of human embryonic stem cells. Reprod. Biomed Online 2002;4:56-61.

57 Wong, RCB, Pebay A, Nguyen LTV, Koh KLL, Pera MF: Presence of functional gap junctions in human embryonic stem cells. Stem Cells 2004;22: 883-889.

58 Oyamada Y, Komatsu K, Kimura H, Mori M, Oyamanda M: Differential regulation of gap junction protein (connexin) genes during cardiomyocytes differentiation of mouse embryonic stem cells in vitro. Exp Cell Res 1996;229:318-326.

59 Baharvand H, Matthaei KI: The ultrastructure of mouse embryonic stem cells. Reprod Biomed Online 2003;7:330-335.

60 Acker JP, Larese A, Yang H, Petrenko A, McGann LE: Intracellular ice formation is affected by cell interactions. Cryobiology 1999;38:363-371.

61 Berger WK, Uhrik B: Freeze-induced shrinkage o individual cells and cell-to-cell propagation of intracellular ice in chains from salivary glands. Experientia 1996;15:843-850.

62 Acker JP, Elliot JAW, McGann LE: Intracellular ice propagation: experimental evidence for ice growth through membrane pores. Biophys J 2001;81: 1389-1397.

63 Irimia D, Karlsson JO: Kinetics and mechanisms of intracellular ice propagation in a micropatterned tissue construct. Biophysics J 2002;82:1858-1868.

64 Toner M, Cravalho EG, Karel M: Thermodynamics and kinetics of intracellular ice formation during freezing of biological cells. J Appl Phys 1990;67: 1582-1593.

65 Acker JP, McGann LE: The role of cell-cell contact on intracellular ice formation. Cryo Lett 1998;19: 367-374.

66 Ji L, de Pablo J, Palacek SP: Cryopreservation of adherent human embryonic stem cells. Biotechnol Bioeng 2004;88:299-312.

67 Heng BC, Ye CP, Lui H, Toh WS, Rufaihah AJ, Bay BH, Ge Z, Ouyang HW, Lee EH, Cao T: Loss of viability during freeze-thaw of intact and adherent human embryonic stem cells with conventional slow-cooling protocols is predominantly due to apoptosis rather than cellular necrosis. J Biomed Sci 2006;13:433-435

68 Heng BC, Ye CP, Lui H, Toh WS, Rufaihah AJ, Cao T: Kinetics of cell death of frozen-thawed human embryonic stem cell colonies is reversibly slowed down by exposure to low temperatures. Zygote 2006;14:341-348.

69 Ware CB, Nelson AM, Blau CA: Controlled-rate freezing of human ES cells. Biotechniques 2005; 38:879-883 
70 Yang PF, Hua TC, Wu J, Chang ZH, Tsung HC, Cao YL: Cryopreservation of human embryonic stem cells: a protocol by programmed cooling. Cryo Lett 2006;27:361-368.

71 Pegg DE, Diaper MP: Freezing versus vitrification: basic principles; in Smit Sibinga CT, Das PC, Meryman HT (eds): Cryopreservation and Low Temperature Biology in Blood Transfusion. Vol 24. Dordrecht, Kluwer, 1990, pp 55-69.

72 Taylor MJ, Song YC, Brockbank KGM: Vitrification in tissue preservation: new developments; in Fuller BJ, Lane N, Benson EE (eds): Life in the Frozen State. London, CRC Press, 2004, pp 603-641.

73 Vajta G, Nagy ZP: Are programmable freezers still needed in the embryo laboratory? Review on vitrification: Reprod Biomed Online 2006;12:779-796.

74 Vajta G, Holm P, Kuwayama M, Booth PJ, Jacobsen $\mathrm{H}$, Greve T, Callensen H: Open pulled straw (OPS) vitrification: a new way to reduce cryoinjuries of bovine ova and embryos. Mol Rep Dev 1999;51: 53-58.

75 Hunt CJ, Timmons PM: Cryopreservation of human embryonic stem cell lines; in Day JG, Stacey G (eds): Cryopreservation and Freeze Drying Protocols. Methods in Molecular Biology. Vol 368. Totowa, Humana Press, 2007, pp 261-270.

-76 Adler S, Pellizzer C, Paparella M, Hartung T, Bremer S: The effects of solvents on embryonic stem cell differentiation. Toxicol In Vitro 2006;20: 265-271.

77 Vajta G, Booth PJ, Holm P, Greve T, Callesen H: Successful vitrification of early stage bovine in vitro produced embryos with the open pulled straw (OPS) method. Cryo Lett 1997;18:191-195.

78 Steyaert SR, Leroux-Rouls GG, Dhont M: Infections in IVF: review and guidelines. Human Reprod Update 2000;6:432-441.

79 Tomlinson M, Sakkas D: Is a review of standard procedures for cryopreservation needed? Safe and effective cryopreservation - should sperm banks and fertility centres move toward storage in nitrogen vapour? Human Reprod 2000;15:2460-2463.
80 Hawkins AE, Zuckerman MA, Briggs M, Gilson RJ, Goldstone AH, Brink NS, Tedder RS: Hepatitis B transmission nucleotide sequence analysis: linking an outbreak of acute hepatitis B to contamination of a cryopreservation tank. J Virol Methods 1996;60:81-88.

81 Mazzilli F, Delfino M, Imbrogno N, Elia J, Dondero F: Survival of micro-organisms in cryostorage of human sperm. Cell Tissue Banking 2006;7:75-79.

82 Tedder RS, Zuckerman MA, Goldstone AH, Hawkins AE, Fieldin A, Briggs EM, Irwin D, Blair S, Gorman AM, Patterson KG, Linch DC, Hepenstall J, Brink NS: Hepatitis B transmission from contaminated cryopreservation tank. Lancet 1995; 346:137-140.

83 NHS Executive: Guidance Notes on the Processing, Storage, and Issue of Bone Marrow and Blood Stem Cells. London, Department of Health, 1997.

84 Rowley SD, Byrne DV: Low-temperature storage of bone marrow in nitrogen vapour-phase refrigerators: decreased temperature gradients with an aluminium racking system. Transfusion 1992;32: 750-754.

85 Hunt CJ, Pegg DE: Improved temperature stability in gas phase nitrogen refrigerators: the use of a copper heat shunt. Cryobiology 1996;33:544-551.

86 Heng BC, Bested SM, Chan SW, Cao T: A proposed design for the cryopreservation of intact and adherent human embryonic stem cell colonies. In Vitro Cell Biol Dev - Animal 2005;41:77-79.

87 Kuleshova LL, Shaw JM, Trounson AO: Studies on replacing most of the cryoprotectant by polymers for embryo cryopreservation. Cryobiology 2001;43: 21-31.

88 Wu CF, Tsung HC, Zhang WJ, Lu JH, Tang ZY, Kuang YP, Jin W, Cui L, Liu W, Cao YL: Improved cryopreservation of human embryonic stem cells with trehalose. Reprod BioMed Online 2005;11: 733-739.

89 Kim SJ, Park JH, Lee JE, Kim JM, Lee JB, Moon SY, Roh SI, Kim CG, Yoon HS: Effects of type IV collagen and laminin on the cryopreservation of human embryonic stem cells. Stem Cells 2004;22: 950-961.
90 Armitage WJ: Osmotic stress as a factor in the detrimental effect of glycerol on human platelets. Cryobiology 1986;23:116-125.

91 Hunt CJ, Pegg DE, Armitage SE: Optimising cryopreservation protocols for haematopoietic cells: a methodological approach for umbilical cord blood. Cryo Lett 2006;27:73-85.

92 Wood EJ, Liu J, Derrow CW, Smith FO, Williams DA, Critser JK: Osmometric and permeability characteristics of human placental/umbilical cord blood CD34+ cells and their application to cryopreservation. J Haematother Stem Cell Res 2000;9: 161-173.

93 Pegg DE: The development of cryopreservation methods for cord blood stem cells. Br Blood Trans Soc Newslett 1996;44.

94 Pegg DE: Viability assays for preserved cells tissues and organs. Cryobiology 1989;26:212-231.

95 Hunt CJ, Armitage SE, Pegg DE: Cryopreservation of umbilical cord blood: 2. Tolerance of CD34+ cells to multimolar dimethyl sulphoxide and the effect of cooling rate on the recovery after freezing and thawing. Cryobiology 2003;46:76-87.

96 Katkov II, Kim MS, Bajpai R, Altman YS, Mercola M, Loring JF, Terskikh AV, Snyder EY, Levine F: Cryopreservation by slow cooling with DMSO diminished production of Oct-4 pluripotency marker in human embryonic stem cells. Cryobiology 2006; 53:194-205.

97 Oh SKW, Choo ABH: Human embryonic stem cells: Technological challenges towards therapy. Clin Exp Pharmacol Physiol 2006;33:489-495.

98 Skottman H, Dilber MS, Hovatta O: The derivation of clinical-grade human embryonic stem cell lines. FEBS Lett 2006;580:2875-2878. 